\title{
PERBEDAAN KADAR KOLESTEROL LDL PENDERITA DISLIPIDEMIA PADA PEMBERIAN TEMPE KEDELAI HITAM DAN TEMPE KEDELAI KUNING
}

\author{
Della Ayuning Priastiti, Niken Puruhita*)
}

Program Studi Ilmu Gizi Fakultas Kedokteran Universitas Diponegoro

Jl.Dr.Sutomo No.14, Semarang, Telp (024) 8453708, Email : gizifk@undip.ac.id

\begin{abstract}
Background: Dyslipidemia leads to a atherosclerosis which is a risk factor for cardiovascular disease. Dyslipidemia is a lipid metabolism disorder which is characterized by increased LDL cholesterol, total cholesterol, trygliseride and decreased HDL cholesterol. Tempeh contains protein and anthocyanin that may influence the decrease of $L D L$ cholesterol. The purpose of this research was to determine the differences effect of black soybean tempeh and yellow soybean tempeh on LDL cholesterol serum in dyslipidemia patient.

Method: This study was a quasi experiment using control group with pre and posttest design. The subjects were 34 menopause women located in Health Community Center of Cirebon who were taken by consecutive sampling. Subjects were into three group; control group, allocated black soybean tempeh group and yellow soybean tempeh group. Along with 14 days intervention process, food intake data was collected using Food Record and Food Recall. LDL cholesterol serum level was measured before and after intervention. Data were analyzed using paired t-test, Wilcoxon, Kruskallwalis Test, and Spearman test.

Result: Black soybean tempeh can decreased LDL cholesterol level by $6.1 \pm 16.45 \mathrm{mg} / \mathrm{dl}$ while yellow soybean tempeh decrease LDL cholesterol level by $4.9 \pm 9.91 \mathrm{mg} / \mathrm{dl}$. The level of LDL in control group increased by $3.5 \pm 19.76 \mathrm{mg} / \mathrm{dl}$. However, the change of LDL cholesterol was not statistically significant ( $p>0 / 05)$

Conclusion: There were trends of decreasing LDL cholesterol level after consumption of black soybean tempeh and yellow soybean tempeh 150 gram per day for 14 days
\end{abstract}

Keyword: Black soybean tempeh; yellow soybean tempeh; dyslipidemia; LDL cholesterol

\begin{abstract}
ABSTRAK
Latar Belakang: Dislipidemia sebagai faktor utama terbentuknya aterosklerosis dan dapat mengakibatkan terjadinya penyakit sirkulasi darah. Dislipidemia merupakan gangguan metabolisme lemak yang ditandai dengan peningkatan maupun penurunan fraksi lemak dalam plasma. Tempe mengandung protein yang berpengaruh terhadap penurunan kolesterol LDL. Penelitian ini bertujuan untuk mengetahui perbedaan pengaruh pemberian tempe kedelai hitam dan tempe kedelai kuning terhadap kolesterol LDL pada penderita dislipidemia.

Metode : Penelitian ini merupakan quasi experiment dengan pre test - post test with control group design. Subjek penelitian adalah wanita menopause yang berdomisili di kawasan Puskesmas wilayah Kabupaten Cirebon yang diambil secara consecutive sampling, besar sampel adalah 34 orang yang dibagi secara acak dalam tiga kelompok. Kelompok kontrol tidak diberi tempe, kelompok perlakuan 1 diberikan tempe kedelai hitam dan kelompok perlakuan 2 diberikan tempe kedelai kuning selama 14 hari. Selama intervensi, asupan makan ketiga kelompok diperoleh dengan metode food record dan food recall. Kadar kolesterol LDL diukur sebelum dan sesudah intervensi. Data yang diperoleh dianalisis menggunakan uji Paired t-test, Wilcoxon, Kruskal Wallis serta uji korelasi Speearman pada derajat kemaknaan $5 \%$.

Hasil : Pada pemberian tempe kedelai hitam terdapat penurunan kadar kolesterol LDL sebesar 6.1 $\pm 16.45 \mathrm{mg} /$ dl

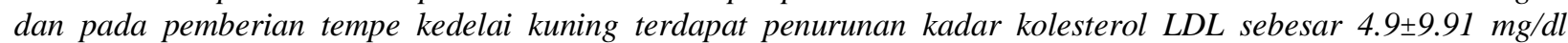
setelah diberikan intervensi selama 14 hari. Sedangkan pada kelompok kontrol terjadi peningkatan kadar kolesterol LDL sebesar $3.5 \pm 19.76 \mathrm{mg} / \mathrm{dl}$. Namun penurunan maupun peningkatan yang terjadi tidak bermakna secara statistik $(p<0.05)$

Simpulan: Terdapat penurunan kadar kolesterol LDL pada pemberian tempe kedelai hitam dan kuning sebesar 150 gram selama 14 hari pada wanita menopause dengan dislipidemia tetapi hasil tersebut tidak bermakna secara statistik.
\end{abstract}

Kata kunci: Tempe kedelai hitam; tempe kedelai kuning; dislipidemia; kolesterol LDL

\section{PENDAHULUAN}

Penyakit sistem sirkulasi darah merupakan penyebab utama morbiditas dan mortalitas di negara maju maupun di negara berkembang. Tahun 2008 menurut data NHLBI penyakit sistem sirkulasi darah di Amerika menyebabkan 812.000

\footnotetext{
${ }^{*}$ Penulis Penanggungjawab
} 
kematian setara dengan 33\% dari seluruh penyebab kematian. $^{1}$ Data RISKESDAS menunjukkan penyakit sistem sirkulasi darah merupakan penyakit dengan urutan teratas sebagai penyakit utama penyebab kematian di rumah sakit baik pada tahun 2007 maupun 2008. Pada tahun 2007 menyebabkan kematian sebanyak 21.830 orang dengan Case Fatality Rate (CFR) 11,02\% dan pada tahun 2008 menyebabkan kematian sebanyak 23.163 orang dengan CFR $11.06 \% .^{2}$ Menurut profil kesehatan Kabupaten Cirebon pada tahun 2006 penyebab teratas kematian pasien rawat inap usia 45-65 tahun dengan CFR 23.49\% dan pada usia >65 tahun dengan CFR $15.32 \%$ adalah penyakit sirkulasi darah. ${ }^{3}$

Penyakit sirkulasi darah disebabkan karena terbentuknya aterosklerosis yang diawali dengan terjadinya dislipidemia. Dislipidemia merupakan gangguan metabolisme lemak yang menyebabkan peningkatan kadar kolesterol total, kolesterol LDL (Low Density Lipoprotein), trigliserida darah, maupun penurunan kolesterol HDL (High Density Lipoprotein) dalam plasma. Terdapat banyak faktor risiko yang mempengaruhi timbulnya aterosklerosis, namun yang merupakan faktor risiko utama adalah peningkatan kadar kolesterol khususnya kolesterol LDL.,5 Deposit kolesterol LDL pada dinding arteri menyebabkan disfungsi endotel, melalui berbagai mekanisme membentuk plak atherosklerosis. Faktor yang berkaitan dengan kadar kolesterol LDL antara lain genetik, jenis kelamin, usia, gaya hidup, dan pola diet seharihari. ${ }^{6,7}$ Pola diet yang salah yaitu kecenderungan konsumsi makananan rendah serat dan tinggi lemak.

Kadar kolesterol darah yang melebihi dari nilai normal akan menyebabkan semakin besar risiko timbulnya plak aterosklerosis. Asosiasi Jantung Amerika menyebutkan kadar kolesterol yang melebihi $250 \mathrm{mg}$ per $100 \mathrm{ml}$ akan meningkatkan risiko PJK sampai tiga kali lipat dibandingkan dengan kadar sebesar $194 \mathrm{mg}$ per $100 \mathrm{mg}$. Penurunan kolesterol LDL sebesar 1 $\mathrm{mg} / \mathrm{dl}$ menurunkan risiko kejadian kardiovaskuler sebesar 1\%. Lipoprotein serum dan level kolesterol dipengaruhi oleh berbagai macam faktor salah satunya diet. ${ }^{8}$

Penurunan kadar kolesterol LDL pada dislipidemia salah satunya dapat dilakukan dengan mengkonsumsi makanan yang dapat memberikan efek hipokolesterolemik. Salah satunya adalah tempe yang merupakan produk fermentasi dengan menggunakan bahan dasar kedelai. Kedelai memberikan banyak manfaat diantaranya dalam pengaturan homeostatis kolesterol. Proses fermentasi kedelai pada tempe menghasilkan tempe memiliki nilai gizi yang lebih baik dibanding kedelai, karena kedelai mengalami berbagai perubahan komposisi oleh proses fisik maupun proses enzimatik akibat aktifitas mikroorganisme. ${ }^{9}$ Senyawa pada tempe yang berpengaruh terhadap penurunan kolesterol antara lain protein, asam lemak tidak jenuh tungal dan majemuk, isoflavon dan anthosianin. Penelitian efek hipokolesterolemik tempe kedelai pada hewan coba dan manusia telah dilakukan oleh beberapa peneliti. Salah satunya penelitian di Bogor menunjukkan bahwa pemberian tempe kedelai kuning sebanyak 160 gram setiap hari selama 4 minggu dapat memperbaiki profil lipid yaitu menurunkan kadar kolesterol total sebesar 6\%, kolesterol LDL sebesar $5.8 \%$ dan TGA sebesar $11.7 \%$, namun tidak dapat meningkatkan kadar kolesterol HDL. ${ }^{10}$

Kedelai yang dibudidayakan di Indonesia terdiri dari dua spesies yaitu Glycine max disebut kedelai kuning yang bijinya bisa berwarna kuning, agak putih, atau hijau, dan Glycine soja disebut kedelai hitam yang memiliki biji hitam. Tempe yang biasa dikonsumsi oleh masyarakat adalah tempe yang berbahan dasar kedelai kuning sedangkan untuk kedelai hitam diproduksi sebagai bahan baku kecap.

Penelitian tentang kedelai hitam masih terbatas pada kandungan senyawa fungsional yang terdapat pada bahan makanan. Aplikasi kedelai hitam pada produk pangan seperti tempe belum dilakukan. Kedelai hitam merupakan salah satu varietas kedelai yang mempunyai banyak kelebihan, baik dari segi kesehatan maupun ekonomis. Kedelai hitam mengandung isoflavon dan antosianin yang berfungsi sebagai antioksidan bagi tubuh. ${ }^{11}$ Kedelai hitam berdasarkan penelitian oleh Takahashi et al, diketahui memiliki kandungan antosianin yang lebih tinggi, yaitu $29 \pm$ $0,56 \mathrm{mg} / \mathrm{g}$ dibandingkan dengan kedelai kuning, $0,45 \pm 0,02 \mathrm{mg} / \mathrm{g}$. Kulit dari kedelai hitam merupakan sumber senyawa antosianin seperti cyanidin-3-glucoside dan delphinidin-3-glucoside. Kandungan antosianin pada kedelai hitam jauh lebih banyak dibanding kedelai kuning karena warna hitam pada kulitnya. ${ }^{12}$ Kedelai hitam yang memiliki antosianin tinggi terbukti dapat menurunkan kadar kolesterol LDL secara signifikan dibandingkan dengan tikus diet tinggi lemak tanpa penambahan ekstrak antosianin kedelai hitam. Antosianin membantu pengeluaran 
kolesterol dari jaringan perifer menuju hepar dan selanjutnya dikeluarkan melalui ekskresi bilier. ${ }^{13}$

Penelitian intervensi konsumsi tempe kedelai kuning dan hitam terhadap kadar kolesterol LDL belum pernah dilakukan pada kelompok rentan khususnya pada wanita menopause. Wanita menopause merupakan kelompok risiko tinggi mengalami dislipidemia. Hal inilah yang mendorong peneliti melakukan penelitian untuk mengetahui perbedaan kadar kolesterol LDL penderita dislipidemia pada pemberian tempe kedelai hitam dan tempe kedelai kuning. Penelitian dilakukan selama 14 hari berdasarkan pada penelitian yang sebelumnya oleh Arbai dengan pemberian tempe 150 gram per hari selama 2 minggu pada laki-laki hiperkolesterol dapat menurunkan kolesterol total sebesar 8.3\%, kolesterol LDL sebesar $8.29 \%$, meningkatkan kolesterol HDL sebesar $8.47 \%$ dan menurunkan rasio kolesterol total terhadap kolesterol HDL sebesar $13.38 \%$. Tempe yang diberikan kepada subjek selama intervensi sebanyak 150 gram dikarenakan pemberian 160 gram tempe sudah dapat memberikan protein yang signifikan $(>50 \%$ $\mathrm{AKG})$.

\section{METODE}

Jenis penelitian ini adalah quasy experiment dengan rancangan pretest postest control group. Penelitian dilakukan di Puskesmas wilayah Kabupaten Cirebon pada bulan AprilSeptember 2012. Subjek penelitian adalah pasien rawat jalan PUSKESMAS wilayah Kabupaten Cirebon. Subjek penelitian yang memenuhi kriteria inklusi diambil secara consecutive sampling, besar subjek penelitian adalah 34 orang yang dibagi secara acak. Penelitian ini digunakan tiga kelompok perlakuan yaitu kelompok kontrol (P0), kelompok perlakuan tempe kedelai hitam (P1) dan kelompok perlakuan tempe kedelai kuning (P2). Kriteria inklusi subjek penelitian antara lain bersedia menjadi subyek penelitian dengan mengisi informed consent, telah mengalami menopause, kadar kolesterol LDL 130mg/dl $190 \mathrm{mg} / \mathrm{dl}$, tidak mengkonsumsi obat-obatan yang mengendalikan kadar kolesterol, dalam keadaan sadar dan dapat diajak komunikasi, dan tidak dalam keadaan sakit. Kriteria eksklusi adalah mengundurkan diri sebagai subjek penelitian, sakit, pada saat masuk fase perlakuan subjek tidak mengkonsumsi tempe selama 3 hari beturut-turut, mengkonsumsi tempe dengan cara digoreng dan diolah dengan santan selama $5 x$ dan subjek tidak memeriksa darah secara lengkap.
Ketiga kelompok diberikan intervensi berupa pengaturan makan sesuai kebutuhan gizi individu. Subjek menyediakan seluruh kebutuhan makannya sendiri kecuali tempe yang disiapkan oleh peneliti. Intervensi dilakukan dengan pemberian tempe kedelai mentah sebanyak 150 gram/hari, diberikan sehari sekali selama 14 hari. Pengolahan tempe kedelai dilakukan oleh subjek dengan ketentuan tidak boleh diolah dengan minyak banyak (digoreng) serta tidak boleh diolah dengan santan dan pemberian tempe kedelai dilakukan secara langsung oleh peneliti. Pada hari ke-15 dilakukan pengukuran kembali kadar kolesterol LDL sebagai data akhir.

Tahap pertama dalam penelitian ini adalah melakukan skrining terhadap semua ibu yang memiliki kolesterol LDL 130 mg/dl-190 mg/dl di setiap puskesmas melalui data sekunder. Peneliti mengunjungi rumah calon subjek satu persatu lalu memberikan penjelasan tentang maksud penelitian, metode penelitian, risiko dan ketidaknyamanan yang akan dialami serta keuntungan yang diperoleh subjek penelitian. Calon subjek yang bersedia mengikuti tahapan penelitian diwajibkan menandatangani informed consent. Setelah ditentukan subjek yang memenuhi kriteria inklusi maka penelitian dapat dilaksanakan. Selanjutnya, dilakukan pengukuran berat badan (BB) dan tinggi badan (TB) untuk mengetahui IMT, serta wawancara data umum subjek.

Pengumpulan data dilakukan dengan wawancara dan pengukuran. Data yang dikumpulkan berupa data primer meliputi data umum subjek, data antropometri, data asupan makan, data kadar kolesterol LDL, data tingkat kepatuhan, dan data aktifitas fisik yang diperoleh melalui wawancara, pengukuran antropometri, dan pengukuran laboratorium. Data yang dikumpulkan melalui wawancara adalah data umum subjek, data asupan makan, tingkat kepatuhan, dan aktifitas fisik. Data yang dikumpulkan melalui pengukuran antropometri adalah data berat badan yang diperoleh melalui penimbangan dengan timbangan digital dengan kapasitas $120 \mathrm{~kg}$ dan ketelitian 0,1 $\mathrm{kg}$, serta data tinggi badan yang diperoleh melalui pengukuran dengan menggunakan mikrotoa dengan kapasitas $200 \mathrm{~cm}$ dan ketelitian $0,1 \mathrm{~cm}$ yang kemudian dicatat pada kuesioner data umum subjek. Hasil pengukuran antropometri diklasifikasikan berdasarkan kriteria WHO Asia Pasifik, yaitu berat badan kurang/underweight $(<$ $\left.18,5 \mathrm{~kg} / \mathrm{m}^{2}\right)$, berat badan normal $(18,5-22,9$ $\left.\mathrm{kg} / \mathrm{m}^{2}\right)$, berat badan lebih/overweight $(23,0-24,9$ 
$\left.\mathrm{kg} / \mathrm{m}^{2}\right)$, obesitas I $\left(25,0-29,9 \mathrm{~kg} / \mathrm{m}^{2}\right)$, dan obesitas II $\left(\geq 30 \mathrm{~kg} / \mathrm{m}^{2}\right)$.

Pengukuran laboratorium untuk kadar kolesterol LDL dilakukan oleh laboratorium "S" yang dilaksanakan sesudah intervensi. Pengambilan sampel darah dilakukan oleh petugas laboratorium setelah subyek berpuasa selama 8 12 jam. Analisis sampel darah dilakukan di laboratorium dengan metode enzymatic colorimetric test dan dinyatakan dalam satuan mg/dl. Deskripsi kadar kolesterol LDL berdasarkan kategori NCEP yaitu optimal/normal ( $<100 \mathrm{mg} / \mathrm{dl})$, mendekati optimal $(100-129 \mathrm{mg} / \mathrm{dl})$, batas tinggi $(130-159 \mathrm{mg} / \mathrm{dl})$, tinggi $(160-189 \mathrm{mg} / \mathrm{dl})$, dan sangat tinggi $(\geq 190)$. Data asupan makanan diperoleh melalui metode food recall 24 jam dan food record selama $14 \times 24$ jam. Hasil recall dalam satuan ukuran rumah tangga (URT) dikonversi ke dalam satuan gram, lalu dianalisis dengan program Nutrisurvey 2005.

Variabel bebas pada penelitian ini adalah asupan tempe kedelai kuning yang merupakan produk fermentasi kedelai varietas Americana dan tempe kedelai hitam yang merupakan produk fermentasi kedelai varietas Shanghai yang diperoleh melalui proses penyortiran, pencucian, perebusan, perendaman selama 1 malam, pencucian, penggilingan, peragian, pencucian, penirisan, pengemasan. Tempe yang diberikan 150 gram selama 14 hari tidak harus dihabiskan pada satu saat tertentu, namun diminta untuk dihabiskan dalam satu hari. Kepatuhan konsumsi tempe, dikontrol dengan menanyakan konsumsi tempe sehari sebelumnya. Variabel terikat adalah kadar kolesterol LDL darah yang diukur setelah subjek penelitian berpuasa selama 8-12 jam, darah diambil pada vena mediana cubiti sebelum dan sesudah intervensi, dengan satuan mg/dl. Variabel perancu yaitu IMT yang diperoleh melalui hasil perhitungan pengukuran berat badan dan tinggi badan. Rerata asupan makan subyek penelitian meliputi asupan energi, protein, lemak, serat, dan kolesterol yang berasal dari makanan dan minuman yang dikonsumsi. Data diperoleh melalui food recall dan food record dalam URT. Data asupan makan subyek diolah dengan Nutrisurvey untuk mendapatkan jumlah asupan sehari-hari.

Perbedaan rerata kadar kolesterol LDL sebelum dan setelah pemberian tempe kedelai pada kelompok P0, P1 dan P2 menggunakan uji Paired t-test pada data yang berdistribusi normal.dan uji Wilcoxon pada data yang tidak berdistribusi normal. Untuk mengetahui perbedaan penurunan kadar kolesterol LDL darah pada ketiga kelompok dilakukan uji Kruskal Wallis. Uji korelasi Spearman untuk mengetahui hubungan antara asupan makan, aktifitas fisik, usia dan IMT terhadap kadar kolesterol LDL.

\section{HASIL PENELITIAN}

Penelitian dilaksanakan di wilayah Puskesmas Kabupaten Cirebon bulan AprilSeptember 2012. Subjek penelitian ini adalah pasien rawat jalan Puskesmas yang memenuhi kriteria inklusi dan eksklusi. Berdasarkan data di Puskemas terdapat 39 subjek yang memenuhi kriteria inklusi. Selama penelitian, 3 subjek dari kelompok perlakuan drop out karena tidak mematuhi prosedur penelitian serta tidak hadir dalam pengambilan darah terakhir dan 2 orang dari kelompok kontrol drop out karena tidak mau melakukan pengambilan darah terakhir. Lima orang mengalami drop out sehingga jumlah akhir subjek penelitian adalah 34 orang. Secara rinci penyusutan subjek tiap kelompok seperti pada Tabel 1.

Tabel 1. Gambaran Jumlah Subjek Setiap Kelompok

\begin{tabular}{|c|c|c|c|c|}
\hline \multirow{2}{*}{ Jumlah Subjek } & \multicolumn{3}{|c|}{ Kelompok Perlakuan } & \multirow{2}{*}{ Total } \\
\hline & P0 & P1 & $\mathbf{P 2}$ & \\
\hline Awal Penelitian & 13 & 12 & 14 & 39 \\
\hline Akhir Penelitian & 11 & 11 & 12 & 34 \\
\hline Alasan & $\begin{array}{l}\text { Tidak hadir } \\
\text { pada saat } \\
\text { pengambilan } \\
\text { darah terakhir }\end{array}$ & Kepatuhan $<70 \%$ & $\begin{array}{l}\text { Kepatuhan } \\
<70 \% \\
\text { Tidak hadir } \\
\text { pada saat } \\
\text { pengambilan } \\
\text { darah } \\
\text { terakhir }\end{array}$ & \\
\hline
\end{tabular}


Tabel 2 berikut menunjukkan karakteristik umum fisik, tingkat pendidikan dan pekerjaan. subjek yang meliputi usia, IMT, tingkat aktivitas

Tabel 2. Deskripsi Karakteristik Tiap Kelompok

\begin{tabular}{|c|c|c|c|}
\hline \multirow{2}{*}{$\begin{array}{c}\text { Karakteristik } \\
\text { Subjek }\end{array}$} & P0 & P1 & P2 \\
\hline & $\mathbf{n}$ & $\mathbf{n}$ & $\mathbf{n}$ \\
\hline \multicolumn{4}{|l|}{ Kelompok Usia } \\
\hline $46-50$ & $1(2.9 \%)$ & $2(5.9 \%)$ & $1(2.9 \%)$ \\
\hline $51-55$ & $5(14.7 \%)$ & $6(17.6 \%)$ & $6(17.6 \%)$ \\
\hline $56-62$ & $5(14.7 \%)$ & $3(8.8 \%)$ & $5(14.7 \%)$ \\
\hline \multicolumn{4}{|l|}{ Indeks Massa Tubuh } \\
\hline Normal (18.5-22.9) & $1(2.9 \%)$ & $1(2.9 \%)$ & $2(5.9 \%)$ \\
\hline Overweight (23- & $3(8.8 \%)$ & $1(2.9 \%)$ & $4(11.8 \%)$ \\
\hline 24.9) & $5(14.7 \%)$ & $8(23.5 \%)$ & $5(14.7 \%)$ \\
\hline Obesitas I (25- & $2(5.9 \%)$ & $1(2.9 \%)$ & $1(2.9 \%)$ \\
\hline 29.9) & & & \\
\hline \multicolumn{4}{|l|}{ Obesitas II $(\geq 30)$} \\
\hline \multicolumn{4}{|l|}{ Tingkat Aktivitas } \\
\hline Fisik & $1(2.9 \%)$ & $0(0 \%)$ & $2(5.9 \%)$ \\
\hline Rendah $(<600)$ & $10(29.4 \%)$ & $10(29.4 \%)$ & $7(20.6 \%)$ \\
\hline Sedang (600-2999) & $0(0 \%)$ & $1(2.9 \%)$ & $3(8.8 \%)$ \\
\hline \multicolumn{4}{|l|}{ Tinggi ( $\geq 3000)$} \\
\hline \multicolumn{4}{|l|}{ Pendidikan } \\
\hline Tidak Sekolah & $2(5.9 \%)$ & $0(0 \%)$ & $0(0 \%)$ \\
\hline SD & $2(5.9 \%)$ & $0(0 \%)$ & $2(5.9 \%)$ \\
\hline SMP & $4(11.8 \%)$ & $4(11.8 \%)$ & $2(5.9 \%)$ \\
\hline SMA & $1(2.9 \%)$ & $3(8.8 \%)$ & $5(14.7 \%)$ \\
\hline Diploma & $1(2.9 \%)$ & $3(8.8 \%)$ & $1(2.9 \%)$ \\
\hline Sarjana & $1(2.9 \%)$ & $1(2.9 \%)$ & $2(5.9 \%)$ \\
\hline \multicolumn{4}{|l|}{ Pekerjaan } \\
\hline IRT & $5(14.7 \%)$ & $8(23.5 \%)$ & $7(20.6 \%)$ \\
\hline PNS & $2(5.9 \%)$ & $1(2.9 \%)$ & $1(2.9 \%)$ \\
\hline Pegawai & $0(0 \%)$ & $1(2.9 \%)$ & $1(2.9 \%)$ \\
\hline Wiraswasta & $4(11.8 \%)$ & $1(2.9 \%)$ & $3(8.8 \%)$ \\
\hline
\end{tabular}

Tabel 2 menunjukkan bahwa sebagian dari subjek penelitian berusia 51-55 tahun (50\%), untuk tingkat aktifitas fisik hampir seluruh subjek berada pada kategori baik pada kelompok perlakuan 1 (29.4\%), perlakuan 2 (20.6\%) dan kontrol (29.4\%). IMT subjek penelitian pada seluruh kelompok berada pada kategori obesitas I. Hampir sebagian besar subjek penelitian memiliki IMT diatas normal (88.2\%), hanya 4 subjek dengan IMT normal. Pekerjaan subjek penelitian sebagian besar merupakan ibu rumah tangga. Tingkat pendidikan subjek penelitian tamat SMP (29.5\%) dan SMA $(26.4 \%)$.

Tabel 3. Perbedaan Rerata Usia, Aktifitas Fisik, dan IMT pada tiap kelompok.

\begin{tabular}{lllll}
\hline \multirow{2}{*}{ Variabel } & \multicolumn{1}{c}{$\begin{array}{c}\text { P0 } \\
(\mathbf{n = 1 1})\end{array}$} & \multicolumn{1}{c}{$\begin{array}{c}\text { P1 } \\
(\mathbf{n = 1 1})\end{array}$} & \multicolumn{1}{c}{$\begin{array}{c}\text { P2 } \\
(\mathbf{n = 1 2})\end{array}$} & \multirow{2}{*}{$\mathbf{p}^{\mathbf{a}}$} \\
\cline { 2 - 4 } & Rerata \pm SB & Rerata \pm SB & Rerata \pm SB & \\
\hline Usia (tahun) & $55.5 \pm 2.51$ & $53.6 \pm 3.69$ & $55.3 \pm 3.47$ & 0.334 \\
\hline Aktifitas fisik $(\mathrm{kkal})$ & $1667.3 \pm 754.96$ & $1774.0 \pm 758.80$ & $2224.3 \pm 1179.64$ & 0.322 \\
\hline IMT $\left(\mathrm{kg} / \mathrm{m}^{2)}\right.$ & $26.5 \pm 2.96$ & $26.7 \pm 2.94$ & $25.6 \pm 3.22$ & 0.633 \\
\hline
\end{tabular}

Ket : a = Uji Annova 
Karakteristik subjek (usia, IMT dan aktifitas fisik) dapat mempengaruhi kadar kolesterol LDL kelompok perlakuan dan kontrol. Uji statistik pada tabel 3. menunjukkan tidak terdapat perbedaan rerata usia, IMT dan aktifitas fisik yang bermakna ( $p>0.05)$ antara kelompok ketiga kelompok tersebut. Hal ini menggambarkan bahwa keadaan awal subjek penelitian adalah homogen.

\section{Keadaan Subjek Penelitian pada Awal Penelitian}

Keadaan awal subjek penelitian disajikan untuk mengetahui perbedaan subjek sebelum intervensi.

Tabel 4. Asupan Makan Sebelum Intervensi

\begin{tabular}{|c|c|c|c|c|c|c|c|}
\hline \multirow[t]{2}{*}{ Variabel } & $\begin{array}{c}\text { P0 } \\
(\mathrm{n}=11)\end{array}$ & \multirow[t]{2}{*}{$\% \mathrm{AKG}$} & $\begin{array}{c}P 1 \\
(n=11)\end{array}$ & \multirow[t]{2}{*}{$\%$ AKG } & $\begin{array}{c}\text { P2 } \\
(\mathrm{n}=12)\end{array}$ & \multirow[t]{2}{*}{ \% AKG } & \multirow[t]{2}{*}{$\mathbf{p}^{\mathbf{a}}$} \\
\hline & Rerata \pm SB & & Rerata \pm SB & & Rerata \pm SB & & \\
\hline $\begin{array}{l}\text { Asupan } \\
\text { energi } \\
\text { (kkal) }\end{array}$ & $1333.5 \pm 115.17$ & $76.2 \%$ & $1553.9 \pm 234.01$ & $88.8 \%$ & $1202.8 \pm 196.8$ & $68.7 \%$ & $\begin{array}{l}0.002 * \\
\mathrm{~b}\end{array}$ \\
\hline $\begin{array}{l}\text { Asupan } \\
\text { lemak } \\
\text { total (gr) }\end{array}$ & $53.3 \pm 14.98$ & $36 \%$ & $52.8 \pm 21.44$ & $30.6 \%$ & $41.5 \pm 14.43$ & $31.1 \%$ & 0.187 \\
\hline $\begin{array}{l}\text { Asupan } \\
\text { protein } \\
\text { (gr) }\end{array}$ & $48.3 \pm 6.68$ & $96.6 \%$ & $53.3 \pm 13.32$ & $106.6 \%$ & $40.8 \pm 10.69$ & $81.6 \%$ & $0.027 *$ \\
\hline $\begin{array}{l}\text { Asupan } \\
\text { serat (gr) }\end{array}$ & $6.3 \pm 2.31$ & & $9.2 \pm 2.14$ & & $6.9 \pm 3.11$ & & $0.025 *$ \\
\hline $\begin{array}{l}\text { Asupan } \\
\text { Kolesterol } \\
(\mathrm{mg})\end{array}$ & $162.1 \pm 104.68$ & & $315.2 \pm 164.72$ & & $182.5 \pm 136.84$ & & 0.047* \\
\hline $\begin{array}{l}\text { Asupan } \\
\text { protein } \\
\text { tempe } \\
(\%)\end{array}$ & $23.6 \pm 15.96$ & & $13.9 \pm 8.71$ & & $14.6 \pm 10.89$ & & 0.131 \\
\hline
\end{tabular}

Ket : a = uji Annova, b= uji Kruskal Wallis, *Signifikan $(\mathrm{p}<0.05)$

Pada analisis statistik, hasil uji beda dari setiap variabel (Tabel 4), menunjukkan bahwa terdapat perbedaan bermakna hampir pada setiap asupan yaitu asupan energi, protein, serat dan asupan kolesterol $(\mathrm{p}<0.05)$. Kelompok yang memiliki perbedaan asupan energi dan kolesterol sebelum intervensi yang bermakna berdasarkan uji analisis Mann Whitney adalah antara kelompok P0 dan P1, serta antara kelompok P1 dan P2. Untuk mengetahui perbedaan bermakna asupan protein dan asupan serat antar kelompok menggunakan analisis Post Hoc metode LSD. Kelompok yang memiliki perbedaan asupan protein yang bermakna yaitu kelompok P2 dengan P1. Kelompok yang memiliki perbedaan asupan serat yang bermakna yaitu kelompok P0 dan P1, serta kelompok P1 dan P2.

\section{Asupan Makan Selama Intervensi}

Faktor yang dapat mempengaruhi kadar kolesterol LDL darah adalah asupan energi, lemak total, protein, kolesterol, serat dan protein tempe. Perbedaan rerata asupan pada ketiga kelompok terlihat pada tabel 5 .

Tabel 5. Asupan Makan Selama Intervensi

\begin{tabular}{|c|c|c|c|c|c|c|c|}
\hline \multirow{2}{*}{ Variabel } & $\begin{array}{c}\mathbf{P 0} \\
(\mathrm{n}=\mathbf{1 1})\end{array}$ & \multirow{2}{*}{$\begin{array}{c}\% \mathbf{A K} \\
\mathbf{G}\end{array}$} & $\begin{array}{c}\mathbf{P 1} \\
(\mathrm{n}=11)\end{array}$ & \multirow{2}{*}{$\begin{array}{c}\% \mathbf{A K} \\
\mathbf{G}\end{array}$} & $\begin{array}{c}\mathbf{P 2} \\
(\mathrm{n}=12)\end{array}$ & \multirow{2}{*}{$\begin{array}{c}\% \mathbf{A K} \\
\mathbf{G}\end{array}$} & \multirow[t]{2}{*}{$\mathbf{p}^{\mathbf{a}}$} \\
\hline & Rerata $\pm \mathrm{SB}$ & & Rerata $\pm \mathrm{SB}$ & & Rerata $\pm \mathrm{SB}$ & & \\
\hline $\begin{array}{l}\text { Asupan } \\
\text { energi (kkal) }\end{array}$ & $\begin{array}{l}1274.4 \pm 103.0 \\
6\end{array}$ & $72.8 \%$ & $\begin{array}{l}1436.2 \pm 213.1 \\
6\end{array}$ & $82.1 \%$ & $\begin{array}{l}1273.9 \pm 190.6 \\
7\end{array}$ & $72.8 \%$ & 0.057 \\
\hline Asupan & $44.3 \pm 12.90$ & $31.3 \%$ & $50.9 \pm 10.07$ & $31.9 \%$ & $43.7 \pm 12.25$ & $30.9 \%$ & 0.287 \\
\hline
\end{tabular}


lemak total

(gr)

\begin{tabular}{|c|c|c|c|c|c|c|c|}
\hline $\begin{array}{l}\text { Asupan } \\
\text { protein (gr) }\end{array}$ & $44.1 \pm 8.68$ & $88.2 \%$ & $56.3 \pm 7.01$ & $\begin{array}{l}112.6 \\
\%\end{array}$ & $46.2 \pm 7.98$ & $92.4 \%$ & $\begin{array}{l}0.002 \\
*\end{array}$ \\
\hline $\begin{array}{l}\text { Asupan serat } \\
\text { (gr) }\end{array}$ & $5.9 \pm 2.72$ & & $7.9 \pm 2.05$ & & $7.2 \pm 1.57$ & & $0.094^{\mathrm{b}}$ \\
\hline $\begin{array}{l}\text { Asupan } \\
\text { kolesterol } \\
(\mathrm{mg})\end{array}$ & $190.1 \pm 42.15$ & & $127.7 \pm 61.70$ & & $96.8 \pm 64.42$ & & $\begin{array}{l}0.001 \\
*\end{array}$ \\
\hline $\begin{array}{l}\text { Asupan } \\
\text { protein tempe } \\
(\%)\end{array}$ & $4.2 \pm 9.15$ & & $40.7 \pm 7.77$ & & $39.3 \pm 6.95$ & & $\begin{array}{l}0.000 \\
*\end{array}$ \\
\hline
\end{tabular}

Ket : a = uji Annova, b= uji Kruskal Wallis, *Signifikan $(\mathrm{p}<0.05)$

Berdasarkan uji yang dilakukan pada tabel 5 terlihat bahwa terdapat perbedaan bermakna $(\mathrm{p}<0.05)$ pada asupan protein, kolesterol dan asupan protein tempe selama intervensi. Perbedaan bermakna pada asupan protein terletak pada kelompok P0 terhadap P1, kelompok P1 terhadap P2. Perbedaan asupan kolesterol yaitu terlihat antara kelompok P0 dan P1, serta antara kelompok P0 dan P2. Perbedaan asupan protein dari tempe yaitu pada kelompok P0 dan P1, serta pada kelompok P0 dan P2. Data yang didapatkan terlihat bahwa terdapat subjek kelompok kontrol yang masih mengkonsumsi tempe walau kecil proporsinya. Hal ini dikarenakan ketidakpatuhan dari beberapa subjek.

Kepatuhan Konsumsi Tempe Kedelai pada Kelompok Perlakuan

Selama penelitian kelompok perlakuan mengkonsumsi tempe kedelai yang diberikan. Rerata asupan tempe kedelai pada kelompok perlakuan adalah $93.55 \%$ pada kelompok P1 dan $81.91 \%$ pada kelompok P2.

Tabel 6. Kepatuhan Konsumsi Tempe Kedelai Pada Kelompok Perlakuan

\begin{tabular}{|c|c|c|c|}
\hline & \multicolumn{2}{|c|}{ Kelompok Perlakuan } & \multirow{2}{*}{$\mathbf{p}^{\mathbf{b}}$} \\
\hline & P1 & P2 & \\
\hline Tingkat & & & $0.011^{*}$ \\
\hline \multirow{2}{*}{\multicolumn{4}{|c|}{$\begin{array}{l}\text { Kepatuhan Asupan } \\
\text { Tempe }\end{array}$}} \\
\hline & & & \\
\hline $70 \%-80 \%$ & $0(0 \%)$ & $7(30.4 \%)$ & \\
\hline $81 \%-90 \%$ & $4(17.4 \%)$ & $2(8.7 \%)$ & \\
\hline $91 \%-100 \%$ & $7(30.4 \%)$ & $3(13 \%)$ & \\
\hline Minimal & $82 \%$ & $72 \%$ & \\
\hline Maksimal & $100 \%$ & $100 \%$ & \\
\hline SB & 7.24 & 10.36 & \\
\hline Rerata & $93.55 \%$ & $81.91 \%$ & \\
\hline
\end{tabular}

Ket $: \mathrm{b}=$ uji Mann Whitney

* Bermakna $(\mathrm{p}<0.05)$

Kepatuhan asupan tempe kedelai subjek berdistribusi tidak normal, kemudian dilakukan transformasi untuk analisis lebih lanjut agar didapatkan data berdistribusi normal. Hasil transformasi menunjukkan variabel tetap berdistribusi tidak normal, sehingga diuji dengan uji Mann Whitney, hasilnya ada perbedaan bermakna kepatuhan konsumsi tempe subjek pada kedua kelompok perlakuan $(\mathrm{p}<0,05)$.

Korelasi Aktivitas Fisik, IMT, Usia, Asupan Energi, As. Lemak, As. Protein, As. Serat, As. Kolesterol dengan Kadar Kolesterol LDL 
Tabel 7. Korelasi Aktivitas Fisik, IMT, Usia, Asupan Energi, As. Lemak, As. Protein, As. Serat, As. Kolesterol dengan Kadar Kolesterol LDL

\begin{tabular}{lll}
\hline & r & pa \\
\hline Kol LDL.Aktifitas fisik & -0.01 & 0.953 \\
Kol LDL. IMT & 0.071 & 0.691 \\
Kol LDL. Usia & -0.16 & 0.366 \\
Kol LDL. As Energi & 0.424 & $0.012^{*}$ \\
Kol LDL. As Lemak & 0.394 & $0.021^{*}$ \\
Kol LDL. As Protein & 0.286 & 0.101 \\
Kol LDL. As Serat & 0.094 & 0.596 \\
Kol LDL. As Kolesterol & 0.288 & 0.099 \\
\hline
\end{tabular}

Ket: a $=$ uji korelasi Spearman

Tabel 7 ini menjelaskan uji korelasi Spearman antara aktifitas fisik, IMT, usia, asupan energi, lemak, serat dan kolesterol dengan kadar kolesterol LDL. Tabel 9 menunjukkan adanya korelasi positif antara asupan energi dan lemak terhadap kadar kolesterol LDL dengan koefisien korelasi yang cukup kuat (nilai $\mathrm{r}>0.025-0.05$ ). Terdapat hubungan bermakna secara statistik antara asupan energi dan lemak terhadap kadar kolesterol LDL. $(\mathrm{p}<0.05)$.

Tidak terdapat hubungan bermakna secara statistik antara aktifitas fisik, IMT, usia, asupan protein, serat dan asupan kolesterol terhadap kadar kolesterol LDL. ( $p>0.05$ ).

Perbedaan Kadar Kolesterol LDL yang Diberi dan Tidak Diberi Tempe Kedelai

Intervensi yang diberikan dalam penelitian ini adalah tempe kedelai hitam dan putih sebanyak 150 gram yang diberikan selama 14 hari. Pengolahan dilakukan oleh subjek penelitian dengan syarat tidak boleh diolah dengan digoreng dan dicampur dengan santan.

Tabel 8. Perbedaan Kolesterol LDL Sebelum dan Setelah Intervensi pada Kelompok Perlakuan dan Kontrol

\begin{tabular}{lcccc}
\hline & \multicolumn{3}{c}{ Kelompok Perlakuan } & P \\
\cline { 2 - 4 } & \multicolumn{2}{c}{ P1 } & P2 & p \\
\hline $\begin{array}{l}\text { Kadar LDL Awal } \\
\text { Rerata } \pm \text { SB }\end{array}$ & $154.0 \pm 9.76$ & $161.3 \pm 24.69$ & $153.7 \pm 33.65$ & $0.230^{\mathrm{a}}$ \\
\hline $\begin{array}{l}\text { Kadar LDL Akhir } \\
\text { Rerata } \pm \text { SB }\end{array}$ & $157.5 \pm 20.28$ & $155.2 \pm 34.48$ & $148.8 \pm 34.09$ & $0.411^{\mathrm{a}}$ \\
\hline P & $0.575^{\mathrm{c}}$ & $0.247^{\mathrm{c}}$ & $0.169^{\mathrm{b}}$ & \\
\hline $\begin{array}{l}\text { Perubahan Kadar } \\
\text { LDL }\end{array}$ & & & & $0.195^{\mathrm{a}}$ \\
Rerata \pm SB & $3.5 \pm 19.76$ & $-6.1 \pm 16.45$ & $-4.9 \pm 9.91$ & \\
\hline
\end{tabular}

Ket $: \mathrm{a}=$ uji Kruskal Wallis, $\mathrm{b}=$ uji Wilcoxon, $\mathrm{c}=$ paired T-test

Pada tabel 8 terlihat penurunan kadar kolesterol LDL baik pada kelompok P1 dan P2 sedangkan pada kelompok P0 terlihat tidak terdapat penurunan kadar kolesterol LDL bahkan terjadi peningkatan kadar kolesterol LDL pada P0 sebesar $3.5 \mathrm{mg} / \mathrm{dl}$. Penurunan kolesterol LDL pada P1 lebih besar dibandingkan dengan penurunan LDL pada P2.

Namun secara statistik tidak terdapat perbedaan bermakna pada P0 ( $>0.05)$ maupun P1 dan $\mathrm{P} 2$ setelah diberikan intervensi $(\mathrm{p}>0.05)$. Tidak terdapat perbedaan yang bermakna kadar kolesterol LDL antar kelompok baik sebelum intervensi $(\mathrm{p}=0.230)$ maupun setelah pemberian intervensi diantara ketiga kelompok tersebut $(\mathrm{p}=0.411)$. Tabel 8 menunjukkan tidak ada perbedaan perubahan kadar kolesterol LDL $(\mathrm{p}=0,195)$ pada kelompok P0, P1 dan P2.

\section{PEMBAHASAN}

Seluruh subjek dalam penelitian ini berjenis kelamin wanita dengan kondisi menopause. Alasan dipilihnya wanita menopause dikarenakan risiko wanita menopause lebih mudah memiliki kolesterol LDL yang lebih tinggi dibandingkan dengan laki-laki dan wanita usia 
produktif. Wanita menopause tidak dapat memproduksi hormon estrogen sebagai hormon yang dapat melindungi wanita dari risiko dislipidemia. Selain itu, wanita memiliki risiko obesitas yang lebih tinggi dibandingkan pria. ${ }^{14}$

Persentase terbesar usia subjek terdapat pada kelompok usia 51-55 tahun. Usia menopause bervariasi dimulai sekitar 45 tahun hingga 55 tahun, yang dapat terjadi secara tiba-tiba atau melalui proses dimana menstruasi terjadi secara tidak teratur menjelang memasuki masa menopause. Nilai total kolesterol dan kolesterol LDL meningkat sejalan dengan meningkatnya usia dikarenakan semakin berkurangnya kemampuan/aktivitas reseptor LDL atau defisiensi reseptor. ${ }^{15}$ Hasil penelitian yang dilakukan oleh Denino dkk ${ }^{16}$ mengemukakan bahwa perubahan kadar kolesterol LDL secara bermakna dipengaruhi oleh usia, dimana pertambahan usia dapat meningkatkan kadar kolesterol LDL. Perubahan profil lipid darah pada wanita usia tua juga disebabkan oleh adanya penurunan hormon estrogen. Hormon estrogen merupakan hormon protektif pada wanita yang berfungsi menurunkan kadar kolesterol LDL. ${ }^{17}$ Hasil penelitian Bhagya $\mathrm{dkk}^{18}$ menunjukkan wanita yang mengalami menopause (46 - 55 tahun) cenderung memiliki kadar serum kolesterol LDL yang lebih tinggi dibanding wanita usia produktif (16 - 45 tahun). .

Sebagian besar $(52.9 \%)$ subjek penelitian termasuk dalam kategori obesitas I. Sebesar $11.7 \%$ memiliki tingkat obesitas II (IMT $\geq 30 \mathrm{~kg} / \mathrm{m}^{2}$ ). Lebih dari setengah subjek penelitian memiliki IMT lebih dari normal. Peningkatan berat badan memperburuk kadar kolesterol LDL dalam darah. Persentase lemak tubuh wanita lebih tinggi dibanding pria. Wanita memiliki akumulasi lemak abdominal dan gluteofemoral lebih banyak dibanding pria sehingga wanita lebih mudah gemuk yang berkaitan dengan risiko obesitas.

Peningkatan kadar kolesterol LDL dikaitkan dengan adanya kandungan lemak tubuh yang juga meningkat seiring dengan pertambahan usia, terutama lemak tubuh yang berada pada area jaringan adiposa viseral. ${ }^{16}$ Jaringan adiposa yang berlokasi dalam rongga perut (abdominal) ini akan melepaskan asam lemak bebas dengan kadar yang tinggi ke dalam sirkulasi portal, sehingga menganggu metabolisme di hati dan merangsang hati memproduksi partikel VLDL, ${ }^{16,19}$ partikel VLDL ini nantinya akan diubah menjadi partikel LDL. ${ }^{20}$ Obesitas meningkatkan produksi apo-B yang terkandung dalam lipoprotein VLDL dan LDL. Oleh karena itu pada orang yang mengalami obesitas terjadi peningkatan kadar kolesterol LDL. ${ }^{21}$ Penurunan berat badan merupakan salah satu cara untuk menurunkan risiko disipidemia. Di samping penurunan berat badan, diperlukan monitoring terhadap kadar kolesterol LDL darah, asupan makan, dan aktifitas fisik untuk menjaga kestabilan kadar kolesterol LDL darah.

Aktifitas fisik memiliki pengaruh yang berbanding terbalik dengan kadar kolesterol LDL darah. Aktivitas fisik yang teratur dapat menurunkan persentasi lemak tubuh dan memberikan pengaruh baik pada profil lipid plasma yang selanjutnya dapat mengurangi risiko menderita obesitas dan penyakit kardiovaskuler. ${ }^{22}$ Hasil dari penelitian ini menunjukkan bahwa aktifitas fisik sebagian besar subjek penelitian (79.4\%) mempunyai tingkat aktifitas sedang dan hanya sebesar $11.7 \%$ subyek memiliki aktifitas yang tergolong tinggi. Uji statistik menunjukkan tidak terdapat perbedaan aktifitas fisik yang bermakna pada kedua kelompok $(\mathrm{p}>0.05)$. Kurangnya aktifitas fisik dapat menjadi faktor yang dapat memperberat kondisi dislipidemia. Salah satu cara untuk meningkatkan aktifitas fisik yaitu dengan berolahraga. Sebanyak $14.7 \%$ subjek penelitian mempunyai kebiasaan olahraga 2 minggu sekali selama 30 menit dengan jenis olahraga senam pagi dan berjalan kaki sedangkan sisanya $85.3 \%$ subjek penelitian tidak pernah melakukan olahraga. Kesibukan di rumah sebagai ibu rumah tangga menyebabkan sebagian besar subjek penelitian tersebut tidak memiliki kebiasaan olahraga. Aktivitas fisik berjalan kaki yang dilakukan secara teratur setiap hari selama 45-60 menit dalam 3 minggu $^{23}$ dan diet rendah lemak tinggi serat dapat memperbaiki semua kondisi lipid serum. Anjuran olahraga yang dikeluarkan oleh Depkes adalah melakukan olahraga secara teratur 3-5 kali per minggu dengan durasi minimal 30 menit. $^{10}$

Asupan makan berpengaruh terhadap kadar kolesterol LDL. Hasil analisis asupan makan dan gizi antar ketiga kelompok relatif sama, baik sebelum dan sesudah intervensi. Untuk menghitung tingkat kecukupan energi dan zat gizi menggunakan Angka Kecukupan Gizi hasil WNPG 2004. Kategori tingkat kecukupan energi dan protein adalah $<70$ persen defisit berat, $70-80$ persen defisit sedang, 80-90 persen defisit ringan, 90-110 persen normal, >110 persen kelebihan. $^{24}$ Rata-rata asupan energi dari ketiga kelompok termasuk ke dalam kategori defisit. Kelompok P1 dengan AKG energi sebesar $88.8 \%$ (defisit ringan), kelompok P2 sebesar $68.7 \%$ (defisit berat), 
kelompok P0 $76.2 \%$ (defisit sedang). Rata-rata kecukupan AKG untuk asupan energi setelah intervensi tidak ditemukan perbedaan yang signifikan. Ketiga kelompok masih termasuk dalam kelompok defisit ringan dan sedang.

Asupan protein sebelum dilakukan intervensi, hanya pada kelompok P2 yang termasuk kedalam kategori defisit ringan (81.6\%), sedangkan kelompok P1 dan P0 memiliki asupan protein yang normal (106.6\%) dan (96.6\%). Namun, setelah intervensi dilakukan rata-rata asupan protein kelompok P2 dan P1 meningkat menjadi sebesar $92.4 \%$ dan $112.6 \%$ sedangkan kelompok P0 rerata asupan protein menurun menjadi defisit ringan $(88.2 \%)$. Hal ini mungkin karena pada kelompok perlakuan telah disediakan tempe yang harus dikonsumsi setiap hari, sedangkan pada kelompok kontrol tidak disediakan dan tidak diperbolehkan mengkonsumsi tempe beserta produk kedelai lainnya sehingga subjek diharuskan mencari makanan pengganti seperti lauk hewani atau mengurangi asupan makanan yang hal tersebut berarti menyebabkan berkurangnya makanan sumber protein.

Menurut ATP III NECP 2002, asupan lemak yang disarankan sebaiknya tidak lebih dari $25 \%$ konsumsi energi. Rerata asupan lemak dilihat dari tabel menunjukkan ketiga kelompok mengalami kelebihan asupan lemak dari anjuran yang diberikan baik sebelum intervensi $(>30 \%)$ maupun setelah intervensi (>30\%). Asupan lemak melebihi batas maksimal, sejalan dengan kadar kolesterol LDL subjek yang cenderung tinggi. Fase menopause dapat memperburuk kadar kolesterol LDL. Asupan lemak total pada kelompok kontrol mengalami penurunan yang cukup besar, hal ini mungkin dikarenakan adanya Hawthorn effect yang terjadi pada kelompok kontrol. Hawthorn effect yaitu perubahan perilaku yang terjadi karena subjek mengetahui posisinya sebagai objek observasi. ${ }^{25}$

Asupan kolesterol masih tergolong normal ( $<200 \mathrm{mg} / \mathrm{hr}$ ) pada semua kelompok baik saat sebelum maupun selama intervensi yaitu kurang dari 200 mg. Kecukupan kolesterol berdasar RDA USA adalah sebesar $200 \mathrm{mg} / \mathrm{hr}$. Namun, dilihat dari tabel asupan kolesterol, terlihat kecenderungan pada kelompok P1 dan P2 mengalami penurunan asupan kolesterol sebesar $188 \mathrm{mg}$ dan $85.7 \mathrm{mg}$ sedangkan kelompok P0 mengalami peningkatan sampai hampir mendekati batas normal (190.1 mg). Kemungkinan karena kelompok intervensi mengkonsumsi tempe intervensi sementara pada kelompok kontrol harus beralih mengkonsumsi makanan lain yang tinggi karbohidrat, lemak dan kolesterol. Diet yang mengandung tinggi karbohidrat, lemak dan kolesterol dapat meningkatkan konsentrasi kolesterol LDL dalam darah yang selanjutnya akan menyebabkan dislipidemia.

Asupan serat ketiga kelompok jauh lebih sedikit dari standar kebutuhan yang ada baik sebelum intervensi maupun setelah intervensi. Kecukupan serat berdasarkan AKG adalah sebesar $25 \mathrm{~g} / \mathrm{hr}$. Sumber serat utama berasal dari sayur dan buah. Rendahnya asupan serat merupakan salah satu faktor risiko terhadap memburuknya profil lipid subjek. Asupan serat selama intervensi pada kelompok P1 (7.9 gr) dan P2 (7.2 gr) lebih tinggi dibandingkan asupan serat pada kelompok P0 (5.9 gr). Pada penelitian ini, asupan serat yang dikonsumsi pada semua kelompok jauh lebih sedikit dari rekomendasi yang dianjurkan sehingga dianggap tidak mempengaruhi penurunan kadar kolesterol LDL pada kedua kelompok.

\section{Korelasi Variabel Perancu Terhadap Kolesterol LDL}

Hasil uji korelasi menunjukkan asupan energi dan lemak selama intervensi memberikan pengaruh yang signifikan terhadap penurunan kadar kolesterol LDL darah. Variabel asupan energi memiliki korelasi positif yang cukup kuat sebesar 0.424 dan variabel asupan lemak memiliki korelasi positif yang cukup kuat sebesar 0.394 terhadap penurunan kadar kolesterol LDL darah. Semakin tinggi asupan energi dan lemak maka kadar kolesterol LDL juga semakin tinggi. Asupan energi subjek dalam jumlah yang tidak berlebihan bahkan cenderung defisit sedangkan asupan lemak subjek melebihi asupan yang dibutuhkan.

Peningkatan kadar kolesterol LDL pada subjek karena rerata asupan makan yang rendah selama penelitian. Lipolisis terjadi dalam jaringan adiposa karena terjadi penurunan cadangan glukosa untuk menghasilkan energi. Pada kondisi ini, tubuh akan meningkatkan lipolisis sehingga akan terjadi peningkatan asam lemak bebas dalam darah. Asam lemak bebas masuk ke dalam hati dan teroksidasi membentuk trigliserida. Trigliserida dan ester kolesterol diangkut keluar dari hati oleh VLDL menuju jaringan ekstrahepatik. Trigliserida dalam VLDL akan dipecah oleh lipoprotein lipase menjadi asam lemak yang akan ditangkap oleh reseptor VLDL pada jaringan ekstrahepatik. VLDL yang kehilangan sebagian besar trigliserida akan berubah menjadi LDL yang kaya kolesterol. Dengan demikian, peningkatan lipolisis subjek 
akan memicu peningkatan asam lemak bebas yang dapat meningkatkan sintesis LDL dalam darah. ${ }^{26,27}$

\section{Perbedaan Kadar Kolesterol LDL Antara Kelompok Perlakuan dan Kontrol}

Rerata kadar kolesterol LDL sebelum intervensi adalah $161.3 \mathrm{mg} / \mathrm{dl}(\mathrm{P} 1), 153.7 \mathrm{mg} / \mathrm{dl}$ (P2) dan $154.0 \mathrm{mg} / \mathrm{dl}(\mathrm{P} 0)$. Rerata kadar kolesterol LDL pada seluruh kelompok tergolong batas tinggi menurut klasifikasi NECP (National Cholesterol Education Program) yang menetapkan kadar kolesterol LDL yang optimal adalah $<130 \mathrm{mg} / \mathrm{dl}$.

Bedasarkan uji statistik, menunjukkan tidak terdapat perbedaan kadar kolesterol LDL secara bermakna pada kelompok P0, P1, dan P2. Perubahan kadar kolesterol LDL yaitu, kelompok kelompok P0 $(3.5 \mathrm{mg} / \mathrm{dl})$, P1 $(-6.1 \mathrm{mg} / \mathrm{dl})$, dan kelompok P2 (-4.9 mg/dl). Hasil penelitian ini berbeda dengan penelitian yang dilakukan oleh Arbai yang memberikan intervensi tempe kedelai kuning $150 \mathrm{~g} / \mathrm{hr}$ selama 2 minggu pada laki-laki dewasa yang hiperlipidemia dengan hasil penelitian menunjukkan terjadinya penurunan kolesterol total $(8.38 \%)$, kolesterol LDL (8.29\%), trigliserida $(9.19 \%)$ dan meningkatkan kolesterol HDL $(8.47 \%)$ serta penelitian yang dilakukan oleh Dyah Mulyati ${ }^{10}$ yang memberikan tempe kedelai kuning sebanyak 160 gram selama 4 minggu pada wanita menopause dapat menurunkan kolesterol LDL sebesar 5.8\%, kolesterol total sebesar 6\% dan TGA sebesar $11.7 \%$ namun tidak dapat meningkatkan kadar kolesterol HDL. Hal ini kemungkinan disebabkan karena waktu yang diperlukan untuk intervensi jauh lebih cepat dari penelitian Dyah Mulyati dan subjek yang digunakan jenis kelaminnya berbeda dengan penelitian Arbai.

Besarnya perubahan parameter sangat tergantung dari besarnya dosis, bentuk intervensi, lama intervensi dilakukan, serta kondisi pre test subjek perlakuan. ${ }^{10}$ Pada kedua kelompok mengalami penurunan LDL kolesterol namun secara statistik penurunan LDL kolesterol tersebut tidak bermakna. Hal yang menyebabkan hasil ini berbeda dari teori mungkin dapat terjadi karena beberapa faktor. Faktor waktu yang diperlukan untuk intervensi yang kurang lama. Faktor kondisi pre test subyek pada awal perlakuan dimana kadar awal LDL kolesterol subjek yang tidak termasuk dalam kategori tinggi (160-189 mg/dl) atau sangat tinggi $(\geq 190 \mathrm{mg} / \mathrm{dl})$ yaitu rerata LDL kelompok P1 sebesar $161.3 \mathrm{mg} / \mathrm{dl}$ dan rerata LDL kelompok P2 sebesar $153.7 \mathrm{mg} / \mathrm{dl}$ sehingga penurunan nilai kolesterol LDL yang terjadi tidak signifikan.
Faktor variabel perancu yang dapat mempengaruhi nilai dari kolesterol LDL yang tidak dianalisis yaitu asupan lemak trans, asupan karbohidrat, lemak jenuh dan genetik.

Hasil dari penelitian ini menunjukkan bahwa pada kelompok kontrol terjadi peningkatan kolesterol LDL sedangkan kedua kelompok yang diberikan intervensi tempe kedelai hitam dan putih mengalami penurunan kolesterol LDL. Walaupun secara statistik hasil yang didapatkan tidak signifikan namun terdapat kecenderungan adanya penurunan kadar kolesterol LDL pada kelompok perlakuan dan peningkatan kadar kolesterol LDL pada kelompok kontrol. Hal tersebut kemungkinan disebabkan karena asupan protein pada kelompok perlakuan lebih tinggi dibanding kelompok kontrol dari jenis sumber protein yang berbeda. Hal ini sesuai dengan penelitian terdahulu dengan intervensi protein kedelai dan isoflavon terhadap profil lipid menunjukkan perubahan dapat dilihat setelah pemberian selama 2 minggu. Asupan protein lebih tinggi pada kelompok perlakuan dibandingkan kelompok kontrol akibat pemberian tempe sebanyak 150 gram selama 14 hari yang dapat termakan rata-rata $93.55 \%$ dan $81.91 \%$ dari yang disediakan. Pada kelompok kontrol karena tidak boleh mengkonsumsi tempe dan produk olahannya selama penelitian, subjek hanya mengkonsumsi lauk yang berupa olahan telur dan ayam yang tidak memberikan pengaruh terhadap penurunan kadar kolesterol LDL.

Asupan protein pada kelompok perlakuan secara kuantitas dan kualitas lebih baik dibanding kelompok kontrol. Protein hewani mempunyai kandungan lisin yang tinggi, yang cenderung untuk meningkatkan insulin darah dan mendorong sintesis kolesterol. Insulin dan glukagon berperan dalam homeostatis lipid dan glukosa. Pada intervensi protein kedelai jangka panjang terjadi peningkatan glukagon sehingga terjadi penurunan rasio insulin/glukagon. Hal tersebut merupakan sebagian peran protein kedelai terhadap efek hipolipidemik. Rasio arginin terhadap lisin yang tinggi pada protein kedelai memungkinkan penurunan sekresi insulin dan meningkatkan sekresi glukagon yang dapat menghambat proses lipogenesis. Arginin akan menahan efek peningkatan kolesterol oleh lisin. Efek ini dilaporkan terjadi pada penderita hiperkolesterolemia. ${ }^{28}$ Penelitian yang dilakukan oleh Dyah Mulyawati ${ }^{10}$ membuktikan bahwa arginin merupakan asam amino yang tertinggi dalam tempe dan penelitian yang dilakukan Ghozali menunjukkan konsentrasi arginin pada 
tempe meningkat hingga tujuh kali dibandingkan arginin pada kedelai.

Kedelai mengandung 2 tipe protein yaitu globulin 11S (glycinin) dan 7S ( $\beta$-conglycinin). Kedua jenis globulin tersebut, terutama $7 \mathrm{~S}$, telah terbukti dapat menstimulir tingginya afinitas reseptor kolesterol LDL dan mendegradasi LDL di sel hepar yang akan menyebabkan penurunan kolesterol darah. Selain itu, efek dari fraksi peptida ini hampir mirip dengan mekanisme penurunan kadar kolesterol oleh komponen kedelai lain yang tidak tercerna tubuh seperti serat yaitu melalui peningkatan sekresi asam empedu dan penghambatan absorbsi kolesterol yang didapatkan dari makanan. Hal ini akan berakibat pada menurunnya kadar kolesterol LDL dalam serum. ${ }^{29}$

Studi pada kultur sel menunjukkan bahwa globulin dapat menstimulasi aktifitas reseptor LDL. Berdasarkan penelitian sebelumnya, Sirtori et al. menyatakan bahwa konsumsi protein kedelai dapat mengatur reseptor LDL pada manusia. Hal ini juga terbukti pada penelitian Baum $e t a l^{30}$ yang menunjukkan peningkatan aktivitas reseptor LDL lebih tinggi pada kelompok yang diberi intervensi protein kedelai dibanding protein kasein melalui peningkatan konsentrasi peningkatan konsentrasi mRNA reseptor LDL hepatik. Protein kedelai menurunkan penyerapan kolesterol dan asam empedu pada usus halus sehingga dapat menginduksi peningkatan ekskresi fekal asam empedu dan steroid. Hal ini mengakibatkan hati lebih banyak merubah kolesterol dalam tubuh menjadi empedu, yang akibatnya dapat menurunkan kolesterol dan meningkatkan aktivitas reseptor kolesterol LDL, yang mengakibatkan peningkatan dalam laju penurunan kadar kolesterol. $^{28}$

Fermentasi kedelai menjadi tempe menghasilkan asam lemak esensial yang bermanfaat. Manfaat tempe bagi kesehatan sebenarnya tidak perlu diragukan lagi. Efek antioksidan pada tempe sebenarnya merupakan hasil dari efek sinergis tocopherol atau vitamin $\mathrm{E}$ pada kedelai dengan asam amino yang dibebaskan selama fermentasi oleh Rhizopus oligosporus yang mengakibatkan timbulnya aktivitas lipase sehingga kadar asam lemak bebas pada tempe lebih tinggi dibanding kedelai. Potensi tempe untuk mencegah oksidasi lemak juga lebih besar dibanding tocopherol.

Kandungan lemak tempe jauh di bawah kandungan lemak hewani dengan kadar protein yang hampir sama dengan tempe. Ikan mas, misalnya, mempunyai kadar lemak 5,8 g dan protein $18,3 \mathrm{~g}$, sementara tempe dengan kandungan lemak jauh dibawah ikan mas, namun mempunyai kandungan protein yang hampir sama yaitu $16,9 \mathrm{~g}$. Sedangkan telur ayam mempunyai kandungan lemak yang jauh lebih tinggi (10,8 g) dibanding tempe namun proteinnya jauh lebih rendah $(12,4$ g).

Tabel 9. Kandungan Lemak dan Asam Lemak per 100 g Tempe Kukus ${ }^{31}$

\begin{tabular}{|c|c|}
\hline Parameter & Hasil (gr) \\
\hline Lemak & 2.89 \\
\hline \multicolumn{2}{|l|}{ Asam Lemak } \\
\hline - Palmitic acid & 7.21 \\
\hline - $\quad$ Stearic acid & 3.05 \\
\hline - Oleic acid & 14.74 \\
\hline - $\quad$ Linoleic acid & 50.12 \\
\hline - $\quad$ Arachidic acid & 0.21 \\
\hline - Linolenic acid & 9.32 \\
\hline - Behenic acid & 0.22 \\
\hline
\end{tabular}

Asam lemak utama pada tempe adalah linoleic acid, secara spesifik dapat dijelaskan bahwa linoleic acid bersifat meningkatkan kolesterol HDL dan menurunkan kolesterol LDL, hal ini berbeda dengan peran asam lemak lainnya yang cenderung bersifat hiperlipidemia. Jika konsumsi energi dari SAFA diganti oleh linoleic acid, maka secara bermakna akan menurunkan kolesterol darah. ${ }^{32}$

Oleic acid adalah asam lemak bebas kedua terbanyak pada tempe setelah linoleic acid. Oleic acid tergolong lemak bebas cis yang bermanfaat bagi tubuh yang jika dikonsumsi sebagai pengganti lemak jenuh (SAFA) akan menurunkan kolesterol darah. Meskipun efek hipokolesterolemia lebih rendah dibanding linoleic acid maupun linolenic acid namun demikian oleic acid punya kemampuan untuk meningkatkan kolesterol HDL merupakan lemak baik yang dapat menurunkan 
risiko penyakit jantung, sehingga oleic acid sering diklaim untuk mencegah penyakit jantung. ${ }^{32}$

Linolenic acid adalah asam lemak bebas ketiga terbanyak dalam tempe. Asam lemak ini dapat lebih efektif menurunkan trigliserida darah dibanding linoleic acid. Namun harus lebih hatihati dalam mengonsumsi karena jika dikonsumsi terlalu tinggi pada individu yang kadar kolesterol LDL awalnya tinggi justru akan semakin meningkatkan kadar kolesterol LDL awal serta menurunkan kadar kolesterol HDL. Selama ini sumber linolenic acid yang popular adalah minyak ikan dan konsumsi dalam dosis tinggi pada orang yang rentan harus dalam pengawasan dokter. Keuntungan dari tempe adalah karena linolenic acid bukan asam lemak bebas utama, sehingga dapat dikonsumsi dalam jumlah banyak tanpa mengurangi manfaatnya. Asam lemak yang dominan adalah linoleic acid sebesar 50,12\%w/w, disusul oleic acid, linolenic acid dan palmitic acid. Semuanya tergolong asam lemak tidak jenuh rantai panjang, sekitar $80 \%$ dari total asam lemak. Asam lemak yang dominan tersebut tergolong esensial yaitu tidak dapat disintesa di dalam tubuh sehingga harus diperoleh dari konsumsi makanan.

Selain itu, tempe mengandung isoflavon kedelai yang mempunyai struktur mirip estrogen akan berinteraksi dengan reseptor estrogen sehingga dapat menurunkan kadar kolesterol melalui mekanisme yang sama, walaupun potensinya lebih kecil $\left(10^{-3}-10^{-5}\right)$ dibanding estrogen sintetis. Isoflavon pada kedelai memiliki efek terhadap reseptor LDL. Isoflavon memberikan efek peningkatan aktivitas up regulating reseptor LDL. Hal ini seperti pada estrogen yang juga memiliki efek peningkatan aktivitas up regulating reseptor LDL. Peningkatan reseptor LDL tersebut akan meningkatkan pembersihan LDL dari peredaran darah sehingga jumlah kolesterol LDL dalam darah berkurang.

Isoflavon kedelai merupakan fitoestrogen yang mempunyai struktur yang mirip estrogen, sehingga bekerja menyerupai estrogen. Estrogen dapat meningkatkan kadar dan produksi apolipoprotein A-1 dan menurunkan aktivitas enzim lipase hepatik dengan menekan transkripsi gen untuk lipase hepatik. Peningkatan produksi apolipoprotein A-1 memberikan kontribusi pada peningkatan HDL nascent dimana dalam perjalanannya akan berubah menjadi $\mathrm{HDL}_{2}$. Hidrolisis fosfolipid HDL dan triasilgliserol memungkinkan $\mathrm{HDL}_{2}$ melepaskan muatan ester kolesterilnya ke dalam hati dimana partikel tersebut menjadi lebih padat dengan membentuk kembali $\mathrm{HDL}_{3}$ yang memasuki kembali siklus HDL sehingga penurunan aktivitas lipase hepatik dapat meningkatkan $\mathrm{HDL}_{2}$, sehingga jumlah kolesterol HDL dalam darah meningkat. Jumlah kolesterol LDL yang menurun dan kolesterol HDL yang meningkat dalam darah akan menurunkan rasio kolesterol LDL/HDL.

Analisis molekular genistein kedelai ternyata memperlihatkan struktur yang mirip dengan 17ß-estradiol, sehingga tergolong sebagai fistoestrogen dan mendukung mekanisme substansi ini dalam perbaikan profil lipid plasma. ${ }^{28}$

Tabel 10. Perbandingan Kandungan Isoflavon Pada Tempe Kedelai Kuning dan Tempe Kedelai Hitam. ${ }^{33}$

\begin{tabular}{ccc}
\hline \multirow{2}{*}{ Isoflavon } & \multicolumn{2}{c}{ Kandungan Isoflavon } \\
\cline { 2 - 3 } & Tempe Kedelai Kuning & Tempe Kedelai Hitam \\
\hline Total Aglycon & 15.7 & 17.4 \\
Daidzein & 8.0 & 6.8 \\
Glycitein & 0.5 & 0.7 \\
Genistein & 7.2 & 9.9 \\
Total glucoside & 87.0 & 85.8 \\
Daidzin & 1.7 & 3.3 \\
Glycitin & 0.4 & 1.0 \\
Genistin & 6.4 & 18.7 \\
Malonyldaidzin & 30.2 & 14.3 \\
Malonylglycitin & 1.4 & 2.7 \\
Malonylgenistin & 41.8 & 38.5 \\
Acetyldaidzin & 0.9 & 1.3 \\
Acetylglycitin & 2.6 & 0.2 \\
Acetylgenistin & 1.6 & 5.8 \\
Total isoflavone & 102.7 & 103.2 \\
(aglycon + glucoside) & & \\
\hline
\end{tabular}


Perbedaan Kadar Kolesterol LDL antara kelompok perlakuan Tempe Kedelai Hitam dan Tempe Kedelai Kuning

Penurunan kolesterol LDL yang terjadi pada kedua kelompok perlakuan menunjukkan kecenderungan penurunan kolesterol LDL yang terjadi lebih besar pada kelompok perlakuan pertama dibandingkan dengan penurunan kolesterol LDL pada kelompok perlakuan kedua. Kemungkinan disebabkan karena efek anthosianin yang terkandung pada kedelai hitam yang memiliki peran dalam penurunan LDL. Antosianin membantu pengeluaran kolesterol dari jaringan perifer menuju hepar dan selanjutnya dikeluarkan melalui ekskresi bilier. Penelitian yang dilakukan Kwon et al. terbukti menurunkan kadar LDL secara signifikan dibandingkan dengan tikus dengan diet tinggi lemak tanpa penambahan ekstrak antosianin kedelai hitam. Penelitian Takahashi et al. $^{34}$ menunjukkan bahwa kedelai hitam memiliki kandungan anthosianin yang lebih tinggi, yaitu $29 \pm 0,56 \mathrm{mg} / \mathrm{g}$, dibandingkan dengan kedelai kuning, $0,45 \pm 0,02 \mathrm{mg} / \mathrm{g}$. Lebih lanjut Takahashi et al. telah membuktikan bahwa kedelai hitam memiliki waktu inhibitor yang lebih lama terhadap oksidasi LDL (205 \pm 16 menit) dibandingkan kedelai kuning $(65 \pm 3$ menit$)$, sehingga resiko terbentuknya plak pada pembuluh darah yang dapat mengakibatkan terjadinya aterosklerosis adalah lebih kecil pada kedelai hitam. ${ }^{9}$

Perlindungan antosianin dan fenolik terhadap LDL dari oksidasi melalui pengikatan atom bebas dan penangkapan radikal bebas. Dorman et.al. memberikan penjelasan yang memungkinkan dari perlindungan LDL oleh efek fenol dan antosianin yaitu ${ }^{35}$ :

a. Menangkap bermacam jenis radikal dalam aqueous phase.

b. Berinteraksi dengan radikal peroksil pada permukaan LDL

c. Masuk ke dalam partikel LDL dan memutuskan reaksi rantai peroksidasi lemak dengan menangkap radikal lemak, dan

d. Meregenerasi $\alpha$-tocopherol dengan menjadikan bentuk aktif antioksidan.

Perubahan kadar kolesterol LDL pada pemberian tempe kedelai kuning dan hitam mengalami penurunan tetapi penurunannya tidak bermakna $(p>0.05)$. Sedangkan pada kelompok kontrol terjadi peningkatan kadar kolesterol LDL namun penurunannya tidak bermakna $(\mathrm{p}>0.05)$. Faktor yang lain yang dapat meningkatkan kadar kolesterol LDL adalah asupan trans fat. Pada penelitian ini tidak meneliti mengenai asupan trans fat, sehingga tidak diketahui efeknya terhadap kadar kolesterol LDL.

Selama intervensi untuk mengetahui asupan makan subjek penelitian digunakan metode food record $14 \times 24$ jam yang dikerjakan oleh subjek penelitian dan food recall $3 \times 24$ jam.

\section{SIMPULAN}

Terdapat penurunan kadar kolesterol LDL sebesar $6.1 \mathrm{mg} / \mathrm{dl}(3.9 \%)$ pada kelompok perlakuan tempe kedelai hitam dan sebesar $4.9 \mathrm{mg} / \mathrm{dl}$ (3.3\%) pada kelompok dengan intervensi tempe kedelai kuning setelah pemberian tempe kedelai sebanyak 150 gram selama 14 hari. Namun, hasil tersebut tidak bermakna secara statistik ( $>00,05)$.

\section{DAFTAR PUSTAKA}

1. National Heart, Lung, and Blood Institute. 2011. [Serial online] [dikutip 8 februari 2013] Available from

http://www.nhlbi.nih.gov/about/factbook/FactBook2 011.pdf

2. Departemen Kesehatan RI. Profil Kesehatan Indonesia 2008. Jakarta: Departemen Kesehatan RI; 2009.

3. Dinas Kesehatan Kabupaten Cirebon. Profil Kesehatan Kabupaten Cirebon 2006. Cirebon: Departemen Kesehatan Cirebon; 2007.

4. Ross R. Atheroscklerosis-an inflammatory disease. $\mathrm{N}$ Engl J Med [serial online] 1999 [cited 2011December22];340(2):115-26. Available from: URL:http://content.nejm.org/cgi/content/full/340/2/1 15

5. Richardson PE, Jones MK, YoungSG, et al. Assembly of lipoprotein particles containing apolipoprotein-B: structural model for the nascent lipoprotein particle. Biophy. J. 2005. 88: 2789-800.

6. Hutter, Carolyn M, Mellisa A, Austin, and Steve E Humphires. Familial hypercholesterolemia, peripheral arterial disease and stroke: a huge minireview. American Journal of Epidemiology.2004; 160(5): 430-435

7. Luley Clause, Gunnar Ronquist, Wolfgabf Reutter, Valerie Paal, Hans Detchlev, Sabine Westphal, et al. Point of care testing of triglycerides, evalution of the accutrend triglycerides system. Clinical Chemistry. 2000; 46:287-291

8. Corwin EJ. Keadaan penyakit atau cidera: Aterosklerosis. In: Pakaryaningsih (ed). Buku Saku Patofisiologi. Jakarta: EGC, 2003, pp: 352-3.

9. Krummel D. Medical Nutrition Therapy in Cardiovascular Disease. In: Mahan LK, Escott SS. Krausse Food, Nutrition and Diet Therapy 11th edition. Pensylvania: Saunders; 2004.p.867-876.

10. Diah MU. Efek Intervensi Tempe Terhadap Profil Lipid, Superoksida Dismutase, LDL Teroksidasi dan 
Malondialdehyde Pada Wanita Menopause [Disertasi]. Program Pasca Sarjana Institut Pertanian Bogor. 2011.

11. Takahashi R, Kiyose C, Momiyama Y, Ohsuzu F, Kondo K. Antioxidant activities of black and yellow soybeans againts low density lipoprotein oxidation. J. Agric Foof Chem. 2005. 53; 4578-82.

12. Astadi IR, Alistair GP. Black soybean (Glycine max L. Merril) seeds' antioxidant capacity. In: Nuts \& Seeds in Health and Disease Prevention $1^{\text {st }}$ Edition. USA; 2011.p.229-236.

13. Kwon SH, Ahn IS, Kim SO, et al. Journal of Medicinal Food. 2007. 10(3): 552-556.

14. Laquatra Idamarie. Nutrition for Weight Management. Dalam : Mahan LK, Stump ES. Krause's Food, Nutrition, and Diet Theraphy $11^{\text {th }}$ edition. Pensylvania : Saunders; 2004. Hal 558-593

15. Vinagre CG, Vinagre CM, Pozzi FS, Maranhão RC. Influence of Aging on Chylomicron Metabolism, Int J Atheroscler. 2007; 2(4):284-288

16. Denino WF, Chernof AT, Dionne IJ, Toth MJ, Ades PA, Sites CK, et al. Contribution of abdominal adiposity to age-related differences in insulin sensitivity and plasma lipids in health nonobese women. Am J Clin Nutr 2001;24:925-32

17. National Cholesterol Education Program. Detection, evaluation, and treatment of high blood cholesterol in adult (Adult treatment panel III). Final report. National Institutes of Health-NIH Publication 2002.

18. Bhagya V, Hemalatha NR, Veeranna HB, Banu V. Serum lipid profile in prepubertal, reproductive and postmenopausal women. Int $\mathrm{J}$ Biol Med Res 2011;2(3):639-42.

19. Miller WM, Janosz KEN, Lillystone M, Yanes J, McCoullough PA. Obesity and lipids. Current Cardiology Reports 2005;7:465-70.

20. Botham KM, Mayes PA. Pengangkutan dan penyimpanan lipid. Dalam : Murray, RK, Granner DK, Rodwell VW. Biokimia harper. $27^{\text {th }}$ ed. JakartaPenerbit Buku Kedokteran EGC; 2009.hal.225-38.

21. Ettinger S. Macronutrients: carbohydrates, proteins, and lipid. In: Mahan LK, Escott SS, Krausse, food, nutrition and diet therapy. 11th ed. Pensylvania: Saunders; 2004. P. 37-62.

22. Anam MS. Pengaruh intervensi diet dan olahraga terhadap indeks massa tubuh, kesegaran jasmani, hsCRP dan profil lipid pada anak obesitas [Tesis]. Program Pasca Sarjana Magister Ilmu Biomedik dan Program Pendidikan Dokter Spesialis Ilmu Kesehatan Anak Universitas Diponegoro Semarang; 2010.

23. Robert CK, Vaziri ND, Barnard RJ. Effects of diet and exercise intervention on blood pressure, insulin, oxidative stress, and nitric oxide availability. Circulation. 2002; 106:2530-2.

24. Hardinsyah DB, Muhilal, Setiawan B, dan Marliyati SA. Efikasi Suplemen Besi-multivitamin Untuk Perbaikan Status Besi Remaja Wanita. Gizi Indon 2007, 30(1): 36-46.
25. William J. Dickson and F. J. Roethlisberger . Counseling in an Organization: A sequel to the Hawthorne Researches. Division of research, Harvard University Graduate School of Business Administration. Boston. 1966. [online]. Available from:

http://www.library.hbs.edu/hc/hawthorne/09.html [Accessed: 14/03/2013]

26. Bender DA dan Mayes PA. Tinjauan umum metabolisme dan penyediaan bahan bakar metabolik. Dalam Murray RK, Granner DK dan Rodwell VW. Biokimia Harper edisi ke-27. Jakarta: Penerbit Buku Kedokteran EGC ; 2006

27. Botham MB dan Mayes PA. Pengangkutan dan penyimpanan lipid. Dalam Murray RK, Granner DK dan Rodwell VW. Biokimia Harper edisi ke-27. Jakarta: Penerbit Buku Kedokteran EGC ; 2006

28. Suprihatin. Optimalisasi Kinerja Reproduksi Tikus Betina Setelah Pemberian Tepung Kedelai dan Tepung Tempe Pada Usia Prapubertas [Tesis]. Program Pascasarjana Institut Pertanian Bogor Bogor. 2008.

29. Arbai, Arsiniati MB. Efek normolitik "tempe A5" dan "tempe" terhadap profil lipid penderita dislipidemia (Disertasi). Program Pascasarjana, Universitas Airlangga Surabaya: 1994.

30. Baum JA, Teng H, Erdman JW Jr, Weigel RM, Klein BP, Persky VW, Freels S, Surya P, Bakhit RM, Ramos E, Shay NF, Potter SM. Long-term intake of soy protein improves blood lipid profiles and increases mononuclear cell low-densitylipoprotein receptor messenger RNA in hypercholesterolemic, postmenopausal women. Am J Clin Nutr. 1998; 68: 545-551.

31. Utari DM. Kandungan Asam Lemak, Zink dan Copper pada Tempe, Bagaimana Potensinya Untuk Mencegah Penyakit Degeneratif?. Departemen Gizi Kesmas Fakultas Kesehatan Masyarakat, UI Gizi Indon 2010, 33(2):108-115

32. Mann, Jim and A. Stewart Truswell (ed). Essentials of human nutrition (Third edition). London: Oxford University Press, 2007.

33. Nakajima N, Nozaki N, Ishihara K, Ishikawa A, Tsuji H. Analysis of Isoflavone Content in Tempeh, a Fermented Soybean, and Preparation of a New Isoflavone-Enriched Tempeh. Journal of Bioscience and Bioengineering. The Society for Biotechnology. Japan. 2005. Vol. 100; No. 6, 685-687.

34. Takahashi R, Kiyose C, Momiyama Y, Ohsuzu F, Kondo K. Antioxidant activities of black and yellow soybeans againts low density lipoprotein oxidation. J. Agric Foof Chem. 2005. 53; 4578-82.

35. Astadi IR, Mary A, Umar S, Prihati SN. In Vitro Antioxidant Activity of Anthocyanins of Black Soybean Seed Coat In Human Low Density Lipoprotein (LDL). Food Chemistry 112. 2009; 659-663. 